\title{
Ethnopharmacological Survey on Medicinal Plants Used by Traditional Healers in Central and Kara Regions of Togo for Antitumor and Chronic Wound Healing Effects
}

\author{
Poyodi Kola $\mathbb{D}^{1},{ }^{1}$ Kossi Metowogo, ${ }^{1}$ Yendubé T. Kantati, ${ }^{1}$ Povi Lawson-Evi, ${ }^{1}$ \\ Mabozou Kpemissi, ${ }^{1}$ Salwa M. El-Hallouty, ${ }^{2}$ Aklesso P. Mouzou, ${ }^{1}$ \\ Kwashie Eklu-Gadegbeku, ${ }^{1}$ and Kodjo A. Aklikokou ${ }^{1}$ \\ ${ }^{1}$ Laboratory of Physiology and Pharmacology, Department of Animal Physiology, Faculty of Sciences, University of Lomé, \\ BP: 1515, Lomé, Togo \\ ${ }^{2}$ Drug Bioassay-Cell Culture Laboratory, Pharmacognosy Department, National Research Center, Dokki, Giza 12622, Egypt \\ Correspondence should be addressed to Poyodi Kola; kolapoyodi@gmail.com
}

Received 9 December 2019; Revised 8 March 2020; Accepted 27 March 2020; Published 14 April 2020

Academic Editor: Juntra Karbwang

Copyright (C) 2020 Poyodi Kola et al. This is an open access article distributed under the Creative Commons Attribution License, which permits unrestricted use, distribution, and reproduction in any medium, provided the original work is properly cited.

\begin{abstract}
Cancer is an emerging public health problem in sub-Saharan Africa. Several medicinal plants are used by traditional healers to treat tumors. In Togo, there are no recorded data for these plants but traditional healers claim to cure tumors with some success. So, information on medicinal plants used to cure human tumors and cancer could be of great importance for their widespread use and scientific validation. The present ethnopharmacological survey aims to record information on antitumor plants in central and Kara regions of Togo. Semistructured validated questionnaires were administered to fifty-seven traditional healers specialized in tumor management in 7 prefectures of Togo. Good practices and know-how were recorded. Quantitative ethnobotanical tools were used to analyze and summarize the data collected. 85 recipes of medicinal plants for tumors management are provided. In the local dialect, $78.95 \%$ of traditional healers do not have a clear tumor designation and $29.90 \%$ find that the causes of tumors remain unknown. According to $48.78 \%$ of traditional healers, the diagnosis of tumors in patients is made in the hospital. The types of tumors frequently treated are those of the breast (43.75\%) and the lung (16.67\%). The seventy listed medicinal plants belong to thirty-nine families, the most represented being Rubiaceae (17.95\%), Caesalpiniaceae (12.82\%), Fabaceae (10.26\%), and Annonaceae (7.69\%). The ten most cited species were Xylopia aethiopica, Aframomum melegueta, Khaya senegalensis, Parkia biglobosa, Piliostigma thonningii, Blighia sapida, Vitellaria paradoxa, Adansonia digitata, Annona muricata, and Parinari curatellifolia. Most of the recipes are prepared as decoction (40\%) and administered orally (54.12\%). Both regions of our study have a wealth of medicinal plants, and traditional healers would use their local knowledge in the management of various tumors and chronic wounds.
\end{abstract}

\section{Introduction}

Noncommunicable diseases are now responsible for the majority of global deaths [1]. Cancer, one of them, is increasingly recognized as a critical public health problem. The International Agency for Research on Cancer estimated 18.1 million new cancer cases for 185 countries of the world and 9.6 million cancer deaths in 2018. In Africa, there were 1.1 million new cancer cases and 0.69 million cancer deaths in
2018 [1]. Estimations suggest that Asia and Africa have the highest proportion of cancer deaths compared with their incidence [1]. It is now well known that apart from the accumulation of mutations, chronic inflammation and chronic wounds lead to cancer in the affected organs [2]. Indeed, chronic wounds due to tissue damage and/or infections could induce chronic oxidative stress and inflammation [3-5]. By these pathways, the generation of free radical, chronic inflammation, and chronic wounds can lead 
to cancer. Then, anticancer products that are able to heal chronic wounds and chronic inflammation and have also radical scavenging are the best for stopping tumor progression [6]. Another approach is to find drugs that possess not only a cytotoxic activity but also an anti-inflammatory and antioxidant activity to fight cancer.

According to the World Health Organization (WHO), about $65-80 \%$ of the world's population in developing countries depends essentially on traditional medicine for their primary health care $[7,8]$. The effectiveness, availability, cost, and minimization of side effects would contribute to this situation [9]. Medicinal plants can play an important role in cancer drug discovery [10]. The main strategies used for the selection of plant species for cancer/ tumor drugs' discovery include random screening, chemotaxonomic information, and ethnomedical knowledge $[11,12]$.

Ethnopharmacological surveys are needed in Africa to identify medicinal plants used by healers to treat several human ailments such as tumors and cancer. These surveys helped record local knowledge of healers and provided a database of plants used traditionally as anticancer plants for further preclinical and clinical studies. In Africa, most published data and ethnopharmacological surveys related to the anticancer potential of plants were from Cameroon, Ghana, Nigeria, Egypt, Madagascar, Morocco, Algeria, and Ethiopia [13-16]. In Togo, some ethnopharmacological surveys have been conducted but they have not focused on cancer [17-21]. The ecological and floristic diversity and the presence of an association of traditional healers practicing in the field support the hypothesis of the availability of potential anticancer plants in Togo. So, the aim of this study was to fulfill the lack of data on plant species used in traditional medicine for cancer management in Togo by interviewing traditional healers. The database of this survey will be used for preclinical studies in order to develop bioactive anticancer drugs.

\section{Methods}

2.1. Study Area. Togo is a Western African country. It is surrounded in the North by the Republic of Burkina Faso, in the East by the Republic of Benin, in the West by the Republic of Ghana, and in the South by the Atlantic Ocean. Togo has been divided into five economic regions from North to South: Savannah region, Kara region, Central region, Plateaux region, and Maritime region. The present ethnopharmacological survey was carried out in two regions (Figure 1): Central and Kara accounting for 7 communities. The area of study is located between $0.61^{\circ}-1.33^{\circ}$ East and $7.89^{\circ}-10.01^{\circ}$ North. With a humid tropical and middle tropical climate, it mainly consists of dry and wooded savannahs, dense dry, and clear forests.

This survey was carried out in close cooperation with the Center for Studies and Research in Applied Traditional Medicine (CERMETRA). This center gathers traditional healers and researchers and is well organized and active in the two regions. The aim of this center is to organize traditional healers in Togo in order to share their knowledge and promote traditional medicine in each region.

2.2. Data Collection. This ethnopharmacological survey was carried out according to the methods of Segun et al. [13], Agyare et al. [16], and Kantati et al. [18]. The survey and data compilation took place from August 2018 to April 2019 in close cooperation with the national staff of CERMETRA based in the Central region. The primary goal of this survey was to collect ethnopharmacological information about medicinal plants for cancer treatment. The participants were selected among traditional healers who are members of CERMETRA and specialized in cancer treatment using medicinal plants. All participants were informed about the survey, and personal visits were made to their usual meeting centers. As Segun et al. [13] and Agyare et al. [16], before the interview, they were informed that some gifts in cash were provided to compensate their time and cost of travelling. The study protocol was approved by the ethics committee, and the informed consent was sought at the beginning of the interview. Fifty-seven traditional healers were interviewed with a semistructured questionnaire. The survey was carried out in two steps: the first step was to meet these traditional healers identified in their usual meeting centers. Information on their identity, the practice of the profession of traditional healers, knowledge of cancer/tumors, and the recipes used, local names, composition, preparation, and collection was requested. The questionnaire is written in French and explained in the local language to traditional healers either by a field assistant of the community or by ourselves depending on the localities.

To ease dialogue with traditional healers and increase the chances of getting useful information, ethnopharmacological usage such as skin disorders, chronic inflammation, tumors, chronic wounds, and malfunctions affecting internal organs can be used as a keyword to reach cancer when selecting plants used to treat cancer $[4,5]$. It is well known that anticancer products that are able to heal chronic wounds and chronic inflammation and have also radical scavenging are the best for stopping tumor progression [22].

The second step of the survey was to go into the bush with a specialist from each community who recognizes the plants. Samples were collected for further systematic identification. Identities of plants' samples collected were confirmed in the herbarium by botanists of the Botany Department, Faculty of Sciences, University of Lomé. Voucher numbers were obtained for all species except four samples (Figure 1) which were deposited also in the herbarium. This is because of the width of the leaves and the difficulty of keeping the bulbs in the form of a herbarium. The taxonomic keys of online databases of PROTA (PROTA4U, Plant Resources of Tropical Africa) and African Plant Database (http://www.theplantlist.org) were used in this process, and the nomenclature of species was done using the online database. 


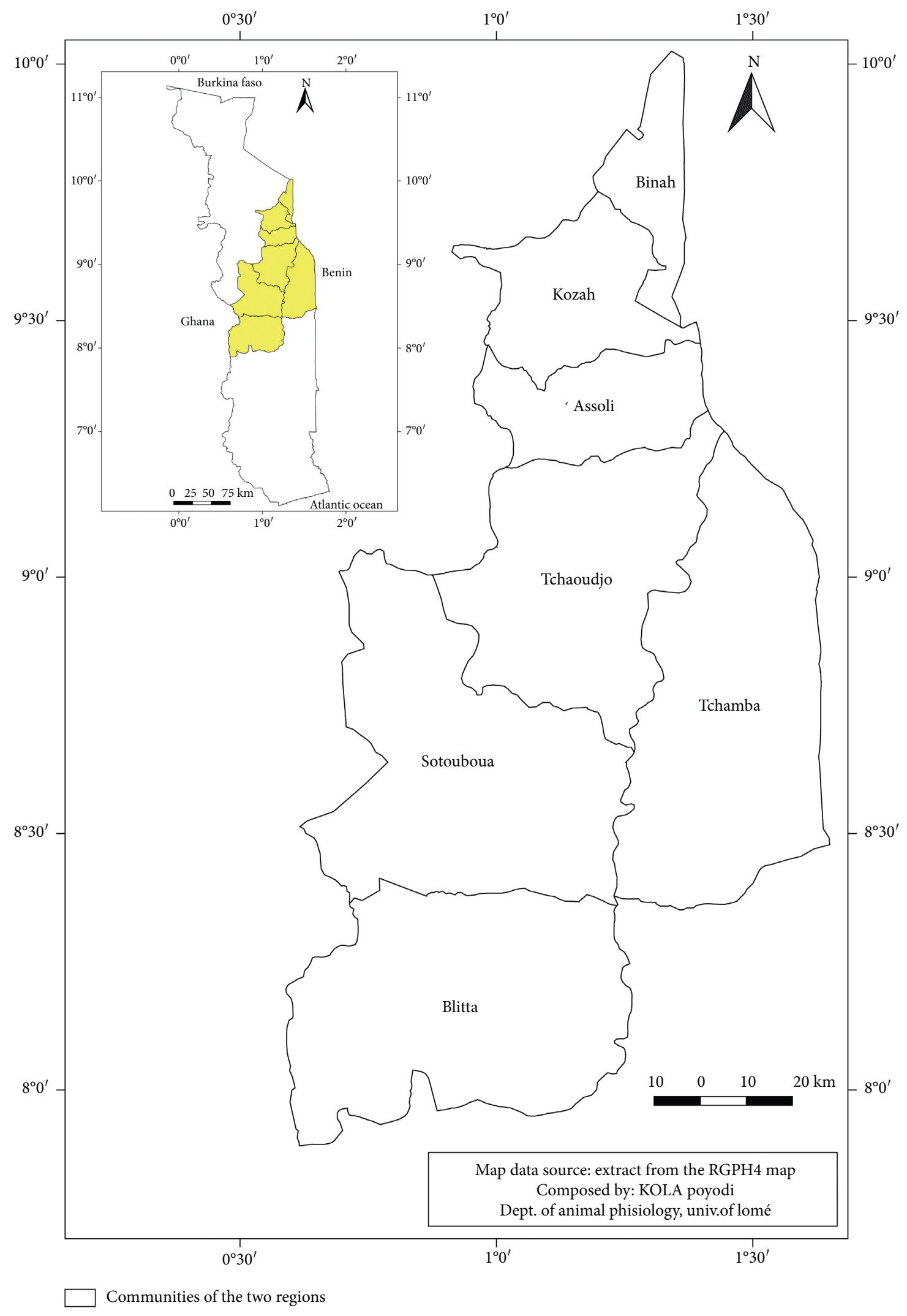

Figure 1: Map of Togo showing the study areas.

2.3. Data Analysis. MS Excel 2013 spreadsheets were used to make simple calculations. The collected data from the survey questionnaire were analyzed using a quantitative method including Fidelity Level (FL), Use Value (UV), and 
Frequency of Citation. This method enables us to make a consensus of the plant species which is frequently used to treat cancer. FL indicates the percentage of informants who claimed to use plant species for the same purpose regarding diseases' treatment. FL $(\%)=\left(N_{p} / N\right) \times 100$, where $N_{p}$ indicates the number of the interviewed healers who claimed to use a plant species to treat a particular disease and $N$ indicates the interviewed healers who used herbs as a medicine to cure any disease [23]. FC $(\%)=$ (number of remedies containing the plant/total of remedies collected) $\times 100$. The use value, a quantitative method that demonstrates the relative importance of species known locally, was also calculated as follows: $\mathrm{UV}=\Sigma \mathrm{U} / n$, where $\mathrm{UV}$ is the use value of a species, $U$ is the number of citations per species, and $n$ is the number of informants [24].

\section{Results and Discussion}

3.1. Characteristics of Traditional Healers. Of the 57 traditional healers surveyed, 50 were men $(87.72 \%)$ and 7 were women (12.28\%). Most of them (85.96\%) inherited the profession of "traditional healer" from their parents. This finding is in agreement with that of Avana-Tientcheu et al. [25] in the Boyo Division in Cameroon. Sixty-eight percent (68\%) of the respondents claimed to have been practicing for $11-50$ years (Figure 2(a)) with the majority (85.96\%) having acquired the knowledge through ancestral inheritance. These findings are similar to those of Agyare et al. [16] and Agyare et al. [26] in Ghana and Segun et al. [13] in Nigeria. This profession requires a long experience for the practitioner to be able to identify plants for effective management of diseases.

Islam (59.65\%) and the traditional religion (28.07\%) were the predominant religions of the respondents. About $21.05 \%$ of the healers were in the age between 20 and 40 years, $66.67 \%$ between 41 and 70 years, and $12.28 \%$ between 70 and 120 years (Figure 2(b)). This age distribution confirms the findings in Togo [17] and is similar to the findings in Ghana and Cameroon $[25,26]$ where a significant dominance of elder or very aged healers was documented. It suggests that the profession of traditional healers was mainly done by elders. In contrast, a trend for youngers in this profession has been reported in a study in Ghana [27].

About healers' education level, 3.51\% held a university degree, $28.07 \%$ attended high and middle school, $24.56 \%$ attended primary school, and $43.86 \%$ were illiterate (Figure 2(c)). In contrast, only 5\% were illiterate or without any formal education in other surveys in Ghana [16].

3.2. Treatment Practices. Cancer designation leads to ambiguous interpretations among traditional healers. In the local language, $78.95 \%$ of traditional healers do not have a common clear local name of tumors and cancer. According to them, it is an emerging disease that did not exist before. Similar observations were made by Segun et al. [13] in Nigeria where interviewers faced the problem of the recognition of the disease by healers. In our study, cancer is perceived as a disease that can attack any part of the body.
The most common cancers they know and treat are breast cancer $(43.75 \%)$ and lung cancer (16.67\%). Segun et al. [13] in Nigeria found that breast, stomach, and skin cancer are the specific types mentioned. This shows that breast cancer is well known by healers as one of the most prevailing cancers in women. The healers of our study area interpret cancer as an incurable wound, wounds that rot, chronic inflammation, swelling, and solid tumors. Segun et al. [13] found similar results. These interpretations are in line with the statement of Ohshima et al. [5] and Aggarwal et al. [3] who underline the link between chronic inflammation, old wounds, and cancer.

In Kabyè dialect, cancer is designated by "Lémiré, Gangang, koudonkissalou, and heimatenmaten"; in kotocoli/Tem by "Abiliou, Feyo, canasseré, and Fézikinlondina"; and in Ewé by "Abidjomakou, Abimakoumakou, and Canssa."

Another important aspect of our findings is that $48.78 \%$ of the traditional healers surveyed stated that their patients were diagnosed in modern hospitals. Due to financial constraints and the lack of appropriate health centers in their area, they choose to be treated by traditional healers. Some traditional healers are able to diagnose certain tumors themselves based on their experience in the field but others send their patients to the hospital for confirmation of the diagnosis. They used certain signs that are frequently encountered in patients such as a lump in the breast and a swelling mainly. They do not fail to make a medical follow-up by analyses during the treatment. These facts show that these healers are able to manage tumors. For $70.30 \%$ of traditional healers, their patients do not receive conventional treatment especially anticancer drugs. Similar cases had been reported by Segun et al. [13] in Nigeria. But in contrast to these findings on cancer diagnosis, Agyare et al. [16] in Ghana found that most of the cancer diagnoses are done by the traditional healers based on their long years of experience and apprenticeship. Few cases are diagnosed at a hospital but prefer to use herbal preparations for the treatment. This depicts a good collaboration between the healer community in the Ashanti region in Ghana and the immense activity of the Ghana Federal Government to increase healers' education level.

During our survey, the healers were asked about the main causes of cancers and tumors in humans in their areas, based on their experience. About 29.9\% of traditional healers stated that the causes of cancers and tumors remain unknown. However, for $22.69 \%$ of the healers, cancer is caused by tobacco smoking and air pollution and food and hygiene for $31.95 \%$ while $6.18 \%$ stated that cancer is caused by a spiritual attack. Only 9.28\% cited that hereditary factors are responsible for cancer. Similar findings were obtained by Agyare et al. [16], and this reflects a quite good understanding of risk factors for oncogenesis. In other studies in Nigeria, beyond half of the healers claimed that cancer is caused by spiritual attack and offence to the gods and abominable things in the family [13]. This suggests that the causes of cancer remain a contradictory debate in the field of traditional medicine because some trust in spiritual attacks 


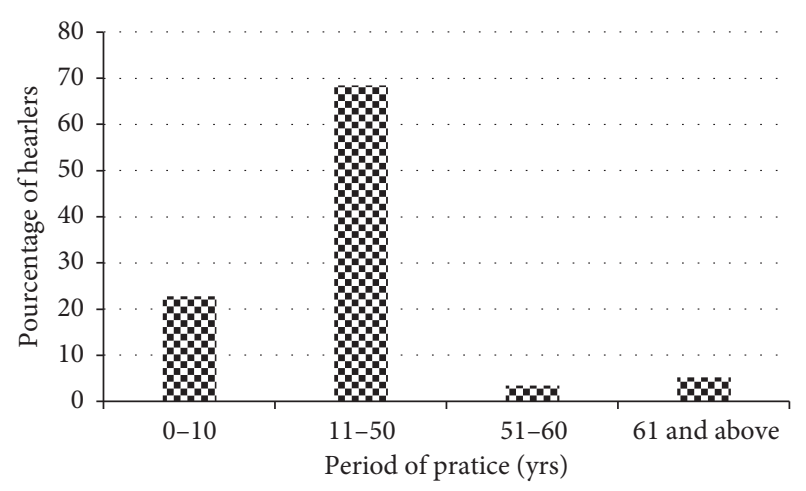

(a)

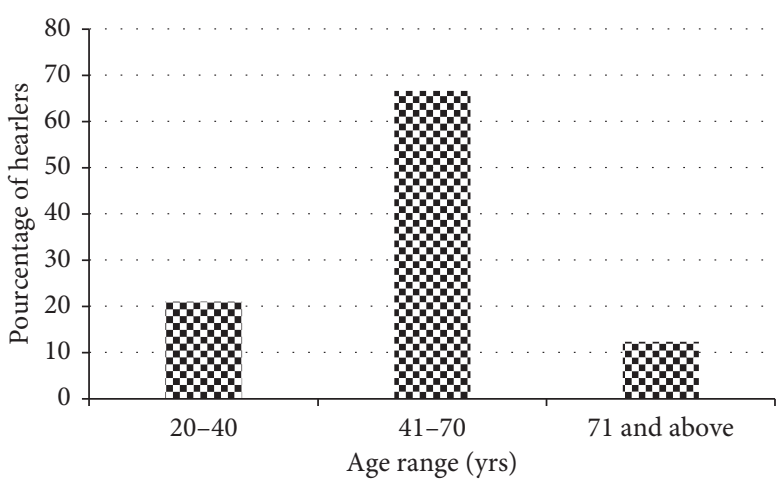

(b)

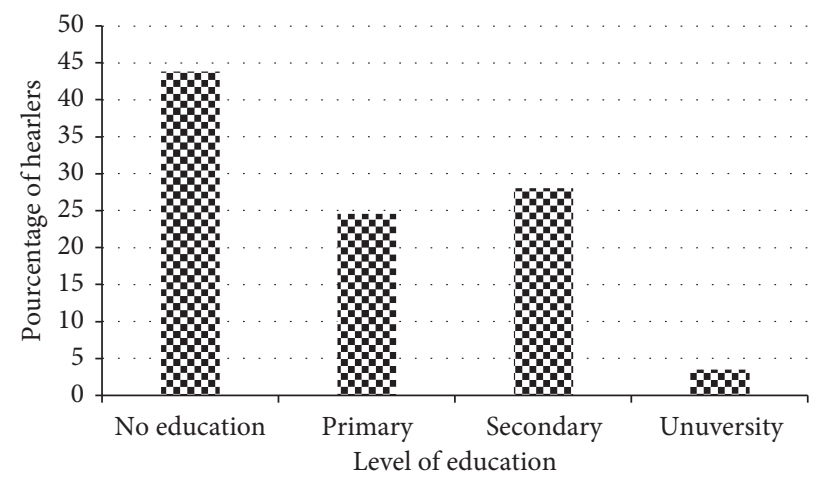

(c)

Figure 2: Biodata analysis of healers. (a) Period of practice. (b) Age range. (c) Distribution of the level of education.

and others rely on genetic and environmental factors similar to the scientists' concepts.

\subsection{Plants Reported as Antitumor and Relative Frequency} Citation. A total of 85 recipes of medicinal plants for tumor management are provided by the 57 traditional healers. These 85 recipes are prepared with 70 different species of plants. These 70 species of medicinal plants distributed among 39 families were identified with their scientific and local names for tumor and related diseases' management in Kara and Central regions of Togo (Table 1). The most represented families are Rubiaceae (17.95\%), Caesalpiniaceae $(12.82 \%)$, Fabaceae (10.26\%), and Annonaceae (7.69\%). The ten most cited species are Xylopia aethiopica, Aframomum melegueta, Khaya senegalensis, Parkia biglobosa, Piliostigma thonningii, Blighia sapida, Vitellaria paradoxa, Adansonia digitata, Annona muricata, and Parinari curatellifolia. Most plant species reported in this study were also reported in other similar studies in Africa $[13,16,25,28]$.

Three groups of medicinal plants recorded in our survey were made (Table 2): group I (very frequently used), group II (frequently used), and group III (less frequently used). The top 10 plants most cited represent $14.28 \%$ of all plants recorded (10/70 plants). A similar observation was made by Agyare et al. [16] in Ghana, where Khaya senegalensis and Blighia sapida, with use values 0.12 and 0.10 , respectively, in our study, are common species most cited in the top 10 species to treat cancer. In a study in Cameroon, Kuete et al. [29] have demonstrated that Xylopia aethiopica, the most used species for cancer in our study, possesses the lowest IC50 on in vitro cytotoxicity on human cancer cells. Aframomum melegueta, a frequent use species in our study for tumors and chronic wounds, is also a frequent use species for wounds in Ghana [26]. Compared to several ethnopharmacological surveys in Nigeria, Ethiopia, Morocco, and Algeria, our top 10 plants most cited are different from their results $[15,28,30]$. This may be due to the difference between flora and geographical characteristics and also knowledge of medicinal plants by healers. In North Africa, among the plethora of plants used, Nigella sativa and Trigonella foenum-graecum are the most preferred ones by herbalists for the treatment of cancer. These wide differences of Africa flora justify the wealth of Africa in plant species that may have anticancer properties.

Chronic inflammation and chronic wounds can lead to cancer in the affected organs. Table 3 shows the list of species cited for the two types of tumors most treated and chronic wound healing in our regions of study. Among our top 10 species, three of them, Piliostigma thonningii, Blighia sapida, and Parinari curatellifolia, are recommended for both types of the most treated tumors (breast and lung) and for old wounds. This suggests an interest for these plants which may possess antitumor and anti-inflammatory effects.

For the formulation of their recipes, $90.77 \%$ of traditional healers find their plant species in the forest only and $7.70 \%$ 
TABLE 1: Medicinal plants used for the management of tumors and chronic wounds in Central and Kara regions of Togo.

\begin{tabular}{|c|c|c|c|c|c|c|c|c|c|}
\hline Plant species & Families & Local name & $\begin{array}{l}\text { Voucher } \\
\text { number }\end{array}$ & $\begin{array}{l}\text { Parts } \\
\text { used }\end{array}$ & $\begin{array}{c}\text { Mode of } \\
\text { preparation/ } \\
\text { administration }\end{array}$ & $\begin{array}{c}\text { Type of } \\
\text { tumors and } \\
\text { chronic } \\
\text { wounds }\end{array}$ & FL & $\begin{array}{l}\mathrm{FC} \\
(\%)\end{array}$ & UV \\
\hline Abrus precatorius $L$. & Fabaceae & $\begin{array}{c}\text { Adodobia fadi/ } \\
\mathrm{T}\end{array}$ & Togo15540 & Le & Pow/Orl & Lung & 1.75 & 1.18 & 0.02 \\
\hline $\begin{array}{l}\text { Acanthospermum } \\
\text { hispidum DC. }\end{array}$ & Asteraceae & Lan gbanisoè/K & Togo15528 & Le & Dec/Orl & Bone, skin & 5.26 & 3.53 & 0.05 \\
\hline Adansonia digitata $\mathrm{L}$. & Bombacaceae & Télou/K & Togo15526 & $\begin{array}{l}\text { Stb, } \\
\text { Fr }\end{array}$ & $\begin{array}{l}\text { Dec, Pow/Top, } \\
\quad \text { Sau/Orl }\end{array}$ & $\begin{array}{c}\text { Chronic } \\
\text { wound, } \\
\text { breast }\end{array}$ & 7.02 & 4.71 & 0.07 \\
\hline $\begin{array}{l}\text { Afraegle paniculata } \\
\text { (Schum.) Engl. }\end{array}$ & Rutaceae & Ngoné/K & Togo15541 & Sed & Pow/Orl & Breast & 1.75 & 1.18 & 0.02 \\
\hline $\begin{array}{l}\text { Aframomum melegueta } \\
\text { K. Schum. }\end{array}$ & Zingiberaceae & Colombo/K & Togo15492 & Fr & $\begin{array}{l}\text { Pow, Dec/Orl/ } \\
\text { Bba/Top }\end{array}$ & $\begin{array}{c}\text { Throat, } \\
\text { bone, breast, } \\
\text { skin, chronic } \\
\text { wound }\end{array}$ & 14.03 & 9.41 & 0.14 \\
\hline $\begin{array}{l}\text { Afzelia africana Sm. ex } \\
\text { Pers. }\end{array}$ & Caesalpiniaceae & Wéré/K & Togo15520 & $\begin{array}{l}\text { Stb, } \\
\text { Rt }\end{array}$ & Pow/Top & $\begin{array}{c}\text { Chronic } \\
\text { wound, skin, } \\
\text { bone }\end{array}$ & 5.26 & 3.53 & 0.05 \\
\hline Allium sativum L. & Alliaceae & Aiyo/E & Togo15542 & Fr & Dec/Orl & Lung & 1.75 & 1.18 & 0.02 \\
\hline Amaranthus hybridus L. & Amaranthaceae & Karatoutou & Togo15532 & Rt, Le & Pow, Top/Orl & $\begin{array}{l}\text { Breast, } \\
\text { cervix }\end{array}$ & 3.51 & 2.35 & 0.03 \\
\hline Annona muricata L. & Annonaceae & Agnigli/E & Togo15173 & Le & Dec/Orl & $\begin{array}{l}\text { Breast, bone, } \\
\text { lung }\end{array}$ & 7.01 & 4.71 & 0.07 \\
\hline $\begin{array}{l}\text { Annona senegalensis } \\
\text { Pers. }\end{array}$ & Annonaceae & Tchoutchourè & Togo15533 & Rt, Le & Pow/Top & $\begin{array}{l}\text { Bone, } \\
\text { chronic } \\
\text { wound }\end{array}$ & 3.51 & 2.35 & 0.03 \\
\hline $\begin{array}{l}\text { Azadirachta indica A. } \\
\text { Juss. }\end{array}$ & Meliaceae & Kini/K & Togo15543 & Stb & Dec/Orl & $\begin{array}{l}\text { Chronic } \\
\text { wound }\end{array}$ & 1.75 & 1.18 & 0.02 \\
\hline $\begin{array}{l}\text { Blighia sapida K. D. } \\
\text { Koenig }\end{array}$ & Sapindaceae & Kpizou & Togo15525 & Le, Fr & $\begin{array}{l}\text { Dec/Top; Sau, } \\
\text { Pow/Orl }\end{array}$ & $\begin{array}{l}\text { Chronic } \\
\text { wound, } \\
\text { lung, skin, } \\
\text { breast, brain }\end{array}$ & 10.53 & 7.06 & 0.10 \\
\hline $\begin{array}{l}\text { Bridelia ferruginea } \\
\text { Benth. }\end{array}$ & Euphorbiaceae & Kolou/T & Togo15504 & Rt & Pow/Top & $\begin{array}{l}\text { Chronic } \\
\text { wound }\end{array}$ & 1.75 & 1.18 & 0.02 \\
\hline $\begin{array}{l}\text { Butia capitata (Mart.) } \\
\text { Becc. }\end{array}$ & Arecaceae & Foda kokolo/K & & $\mathrm{Rt} / \mathrm{Fr}$ & Dec/Orl & Breast & 1.75 & 1.18 & 0.02 \\
\hline $\begin{array}{l}\text { Caesalpinia pulcherrima } \\
\text { (L.) Sw. }\end{array}$ & Caesalpiniaceae & Wayi/K & Togo15506 & Le & Dec/Orl & Prostate & 1.75 & 1.18 & 0.02 \\
\hline $\begin{array}{l}\text { Calotropis procera } \\
\text { (Aiton) R. Br. }\end{array}$ & Asclepiadaceae & Kpakpadjoé/K & Togo15534 & Rt, Le & Dec/Orl, top & $\begin{array}{l}\text { Breast, } \\
\text { chronic } \\
\text { wound }\end{array}$ & 3.51 & 2.35 & 0.03 \\
\hline Carica papaya L. & Caricaceae & Somboré/K & Togo15544 & Rt & Pow/Orl & Lung & 1.75 & 1.18 & 0.02 \\
\hline $\begin{array}{l}\text { Citrus limon (L.) Burm. } \\
f .\end{array}$ & Rutaceae & Gnami/K & Togo15497 & Fr & $\mathrm{Mac} / \mathrm{Orl}$ & Lung, breast & 5.26 & 3.53 & 0.05 \\
\hline $\begin{array}{l}\text { Cochlospermum } \\
\text { planchonii Hook. F. }\end{array}$ & Cochlospermaceae & Tèkalichoua/K & Togo15501 & Rt & Pow/Orl & Breast & 1.75 & 1.18 & 0.02 \\
\hline $\begin{array}{l}\text { Cola nitida (Vent.) } \\
\text { Schott \& Endl. }\end{array}$ & Sterculiaceae & Coroo/T & Togo15551 & Hul & Pow/Top & Breast & 1.75 & 1.18 & 0.02 \\
\hline $\begin{array}{l}\text { Colocasia esculenta (L.) } \\
\text { Schott }\end{array}$ & Araceae & Pankani/K & Togo15546 & Le & Pow/Orl & Breast & 1.75 & 1.18 & 0.02 \\
\hline $\begin{array}{l}\text { Combretum collinum } \\
\text { Fresen. }\end{array}$ & Combretaceae & Fokizao/T & Togo15507 & Rt & Sau/Orl & Lung & 1.75 & 1.18 & 0.02 \\
\hline Curcuma longa $L$. & Zingiberaceae & Wissikoyè & Togo15496 & Rt & Pow/Orl & Breast & 1.75 & 1.18 & 0.02 \\
\hline $\begin{array}{l}\text { Daniellia oliveri (Rolfe) } \\
\text { Hutch. \& Dalziel }\end{array}$ & Caesalpiniaceae & Tchèlè/T & Togo15547 & Le & Sau/Orl & Lung & 1.75 & 1.18 & 0.02 \\
\hline $\begin{array}{l}\text { Dichrostachys cinerea } \\
\text { (L.) Wight and Arn. }\end{array}$ & Mimosaceae & Sozossi/T & Togo15548 & Rt & $\mathrm{Sau} / \mathrm{Orl}$ & Breast & 1.75 & 1.18 & 0.02 \\
\hline $\begin{array}{l}\text { Elaeis guineensis } f . \\
\text { androgyna A. Chev. }\end{array}$ & Arecaceae & Pawou/K & & Rt & $\mathrm{Dec} / \mathrm{Orl} / \mathrm{Bba}$ & $\begin{array}{l}\text { Chronic } \\
\text { wound }\end{array}$ & 1.75 & 1.18 & 0.02 \\
\hline
\end{tabular}


TABle 1: Continued.

\begin{tabular}{|c|c|c|c|c|c|c|c|c|c|}
\hline Plant species & Families & Local name & $\begin{array}{l}\text { Voucher } \\
\text { number }\end{array}$ & $\begin{array}{l}\text { Parts } \\
\text { used }\end{array}$ & $\begin{array}{c}\text { Mode of } \\
\text { preparation/ } \\
\text { administration }\end{array}$ & $\begin{array}{l}\text { Type of } \\
\text { tumors and } \\
\text { chronic } \\
\text { wounds }\end{array}$ & FL & $\begin{array}{l}\mathrm{FC} \\
(\%)\end{array}$ & UV \\
\hline $\begin{array}{l}\text { Eleusine indica (L.) } \\
\text { Gaertn. }\end{array}$ & Poaceae & Adandala/T & Togo15502 & Rt & Pow/Top & Breast & 1.75 & 1.18 & 0.02 \\
\hline $\begin{array}{l}\text { Erythrina senegalensis A. } \\
\text { DC. }\end{array}$ & Fabaceae & $\begin{array}{l}\text { Gbengben } \\
\text { tchikoloka/T }\end{array}$ & Togo15549 & Rt & Pow/Top & $\begin{array}{l}\text { Throat } \\
\text { wound }\end{array}$ & 1.75 & 1.18 & 0.02 \\
\hline $\begin{array}{l}\text { Fadogia agrestis } \\
\text { Schweinf. ex Hiern }\end{array}$ & Rubiaceae & $\begin{array}{c}\text { Djangadjanga/ } \\
\mathrm{T}\end{array}$ & Togo15550 & Rt & Dec/Orl & Liver & 1.75 & 1.18 & 0.02 \\
\hline $\begin{array}{l}\text { Gardenia ternifolia } \\
\text { Schumach. \& Thonn. }\end{array}$ & Rubiaceae & $\mathrm{Kao} / \mathrm{K}$ & Togo15505 & Rt & Dec/Orl & Breast & 1.75 & 1.18 & 0.02 \\
\hline $\begin{array}{l}\text { Gymnosporia } \\
\text { senegalensis (Lam.) Loes. }\end{array}$ & Celastraceae & $\begin{array}{c}\text { Tchakatchaka/ } \\
\text { K }\end{array}$ & Togo15535 & Le & Dec, Orl/Top & $\begin{array}{l}\text { Chronic } \\
\text { wound }\end{array}$ & 1.75 & 2.35 & 0.03 \\
\hline $\begin{array}{l}\text { Khaya senegalensis } \\
\text { (Desr.) A. Juss. }\end{array}$ & Meliaceae & $\begin{array}{l}\text { Hemou/K, } \\
\text { Frimou/T }\end{array}$ & Togo15523 & $\begin{array}{l}\text { Stb, } \\
\text { Le }\end{array}$ & $\begin{array}{c}\text { Dec, Pow, Mac, } \\
\text { Orl/Bba/Nas }\end{array}$ & $\begin{array}{l}\text { Chronic } \\
\text { wound, skin, } \\
\text { brain, bone }\end{array}$ & 1.75 & 8.24 & 0.12 \\
\hline $\begin{array}{l}\text { Kigelia africana (Lam.) } \\
\text { Benth. }\end{array}$ & Bignoniaceae & $\begin{array}{l}\text { Abiliou/T; } \\
\text { Lémiré/K }\end{array}$ & Togo15529 & Le/Stb & $\mathrm{Mac} / \mathrm{Bba}$ & Breast & 5.26 & 3.53 & 0.05 \\
\hline Lannea acida A. Rich. & Anacardiaceae & Kèlo/T & Togol5552 & Rt & Pow/Top & $\begin{array}{l}\text { Chronic } \\
\text { wound }\end{array}$ & 1.75 & 1.18 & 0.02 \\
\hline Mangifera indica L. & Anacardiaceae & Mango/K & Togo15493 & Le, stb & Dec/Orl & $\begin{array}{l}\text { Chronic } \\
\text { wound, } \\
\text { breast }\end{array}$ & 5.26 & 3.53 & 0.05 \\
\hline Momordica charantia L. & Cucurbitaceae & Katchala & Togo15503 & Le & Pow/Orl & Brain & 1.75 & 1.18 & 0.02 \\
\hline Morinda citrifolia L. & Rubiaceae & Noni & Tog & $\mathrm{Fe}$ & $\mathrm{rl}$ & Breast & 1.75 & 1.18 & 0.02 \\
\hline Moringa oleifera Lam. & Moringaceae & Kpadadrè/K & 5536 & $\mathrm{Le} / \mathrm{Se}$ & Pow/Orl & & 3.51 & 2.35 & 0.03 \\
\hline Musa acuminata Colla & Musaceae & Akori/K & & Pul & Pow/Top & $\begin{array}{l}\text { Skin, } \\
\text { chronic } \\
\text { wound }\end{array}$ & 3.51 & 2.35 & 0.03 \\
\hline Nicotiana tabacum L. & Solanaceae & $\mathrm{Taba} / \mathrm{K}$ & Togo15554 & Le & Dec/Orl & $\begin{array}{l}\text { Chronic } \\
\text { wound }\end{array}$ & 1.75 & 1.18 & 0.02 \\
\hline Ocimum basilicum L. & Lamiaceae & $\begin{array}{c}\text { Konzonzonga/ } \\
\mathrm{K}\end{array}$ & Togo15555 & Le & Pow/Top & Skin & 1.75 & 1.18 & 0.02 \\
\hline Ocimum gratissimum L. & Lamiaceae & $\begin{array}{l}\text { Azèou/K; } \\
\text { Estro/E }\end{array}$ & Togo15530 & Le & $\begin{array}{l}\text { Dec, Mac/Orl; } \\
\text { Pow/Nas }\end{array}$ & $\begin{array}{l}\text { Lung, brain, } \\
\text { breast }\end{array}$ & 5.26 & 3.53 & 0.05 \\
\hline Opilia amentacea Roxb. & Opiliaceae & Kalibinou/K & Togo15517 & Rt & Dec/Orl & Lung & 1.75 & 1.18 & 0.02 \\
\hline $\begin{array}{l}\text { Ornithogalum caudatum } \\
\text { Aiton }\end{array}$ & Hyacinthaceae & Aléwa gabou/K & & $\mathrm{Bu}$ & $\mathrm{Dec} / \mathrm{Bba}$ & Breast & 1.75 & 1.18 & 0.02 \\
\hline Panax gingeng & Araliaceae & Ginseng & Togo15521 & Rt & Dec/Orl & $\begin{array}{l}\text { Lung } \\
\text { Lung, }\end{array}$ & 1.75 & 1.18 & 0.02 \\
\hline $\begin{array}{l}\text { Parinari curatellifolia } \\
\text { Planch. ex Benth. }\end{array}$ & Chrysobalanaceae & Milioumiliou/T & Togo15527 & $\begin{array}{l}\text { Le, Rt, } \\
\text { Rtb }\end{array}$ & $\begin{array}{l}\text { Sau, Dec, Pow/ } \\
\text { Orl }\end{array}$ & $\begin{array}{l}\text { chronic } \\
\text { wound, } \\
\text { breast }\end{array}$ & 7.02 & 4.71 & 0.07 \\
\hline $\begin{array}{l}\text { Parkia biglobosa (Jacq.) } \\
\text { R. Br. ex G. Don }\end{array}$ & Mimosaceae & Soulou/K & Togo15524 & Rt, stb & $\mathrm{Dec} / \mathrm{Orl} / \mathrm{Bba}$ & $\begin{array}{l}\text { Chronic } \\
\text { wound, } \\
\text { breast }\end{array}$ & 12.28 & 8.24 & 0.12 \\
\hline Paullinia pinnata L. & Sapindaceae & Adji kpizou/K & Togo15498 & Le, rt & $\begin{array}{c}\text { Dec, Pow, Orl/ } \\
\text { Top }\end{array}$ & $\begin{array}{l}\text { Chronic } \\
\text { wound }\end{array}$ & 3.51 & 2.35 & 0.03 \\
\hline $\begin{array}{l}\text { Pericopsis laxiflora } \\
\text { (Benth.) Meeuwen }\end{array}$ & Fabaceae & Kodolia/T & Togo15519 & Le, Rt & $\mathrm{Dec} / \mathrm{Orl} / \mathrm{Bba}$ & $\begin{array}{l}\text { Bone, } \\
\text { chronic } \\
\text { wound }\end{array}$ & 3.51 & 2.35 & 0.03 \\
\hline $\begin{array}{l}\text { Phyllanthus } \\
\text { muellerianus (Kuntze) } \\
\text { Exell. }\end{array}$ & Euphorbiaceae & Nbiré Nbiré/T & Togo15556 & Rt & Dec/Orl & Bone & 1.75 & 1.18 & 0.02 \\
\hline Physalis angulata $\mathrm{L}$. & Solanaceae & Ribomboni/T & Togo15557 & Stb & Pow/Orl & $\begin{array}{l}\text { Chronic } \\
\text { wound }\end{array}$ & 1.75 & 1.18 & 0.02 \\
\hline
\end{tabular}


TABle 1: Continued.

\begin{tabular}{|c|c|c|c|c|c|c|c|c|c|}
\hline Plant species & Families & Local name & $\begin{array}{l}\text { Voucher } \\
\text { number }\end{array}$ & $\begin{array}{l}\text { Parts } \\
\text { used }\end{array}$ & $\begin{array}{c}\text { Mode of } \\
\text { preparation/ } \\
\text { administration }\end{array}$ & $\begin{array}{l}\text { Type of } \\
\text { tumors and } \\
\text { chronic } \\
\text { wounds }\end{array}$ & FL & $\begin{array}{l}\mathrm{FC} \\
(\%)\end{array}$ & UV \\
\hline $\begin{array}{l}\text { Piliostigma thonningii } \\
\text { (Schumach.) Milne- } \\
\text { Redh }\end{array}$ & Caesalpiniaceae & $\begin{array}{c}\text { Eclo/E, } \\
\text { Babakou/K }\end{array}$ & Togo15494 & Le, rt & $\begin{array}{l}\text { Pow/Top, Sau/ } \\
\text { Orl }\end{array}$ & $\begin{array}{l}\text { Skin, lung, } \\
\text { chronic } \\
\text { wound, } \\
\text { prostate, } \\
\text { breast }\end{array}$ & 12.28 & 8.24 & 0.12 \\
\hline $\begin{array}{l}\text { Piper guineense } \\
\text { Schumach. \& Thonn. }\end{array}$ & Piperaceae & Atigali/K & Togo15558 & Fr & Dec/Orl & $\begin{array}{l}\text { Chronic } \\
\text { wound }\end{array}$ & 1.75 & 1.18 & 0.02 \\
\hline Plumeria alba L. & Apocynaceae & Ventupanier & Togo15560 & $\begin{array}{l}\text { Le, } \\
\text { Stb }\end{array}$ & Dec/Top & $\begin{array}{l}\text { Chronic } \\
\text { wound }\end{array}$ & 1.75 & 1.18 & 0.02 \\
\hline $\begin{array}{l}\text { Pseudocedrela kotschyi } \\
\text { (Schweinf.) Harms }\end{array}$ & Meliaceae & Doutotoré/T & Togo15518 & Rt, Le & $\begin{array}{c}\text { Mac, } \mathrm{Dec} / \mathrm{Orl}, \\
\mathrm{Bba}\end{array}$ & Breast, bone & 3.51 & 2.35 & 0.03 \\
\hline $\begin{array}{l}\text { Pteleopsis suberosa Engl. } \\
\text { \& Diels }\end{array}$ & Combretaceae & Sisinon/T & Togo15559 & Le & Pow/Orl & $\begin{array}{l}\text { Chronic } \\
\text { wound }\end{array}$ & 1.75 & 1.18 & 0.02 \\
\hline $\begin{array}{l}\text { Sarcocephalus latifolius } \\
\text { (Sm.) E. A. Bruce }\end{array}$ & Rubiaceae & $\begin{array}{c}\text { Kitchatchalou/ } \\
\mathrm{T}\end{array}$ & Togo15553 & $\begin{array}{l}\text { Rt, } \\
\text { Stb }\end{array}$ & Pow, Orl/Top & $\begin{array}{l}\text { Lung, } \\
\text { chronic } \\
\text { wound }\end{array}$ & 1.75 & 1.18 & 0.02 \\
\hline $\begin{array}{l}\text { Securidaca } \\
\text { longipedonculata Fres. }\end{array}$ & Polygalaceae & Fozi/T & Togo15531 & Rt & $\begin{array}{c}\text { Mac, pow, Bba/ } \\
\text { Top/Nas }\end{array}$ & $\begin{array}{l}\text { Breast, bone, } \\
\text { brain }\end{array}$ & 1.75 & 3.53 & 0.05 \\
\hline $\begin{array}{l}\text { Senna siamea (Lam.) H. } \\
\text { S. Irwin \& Barneby }\end{array}$ & Fabaceae & Zanguerati/E & Togo15545 & Le & Dec, Orl & Lung & 1.75 & 1.18 & 0.02 \\
\hline Sesamum indicum L. & Pedaliaceae & Goussi/E & Togo15495 & Fr & $\mathrm{Sau} / \mathrm{Orl}$ & Breast & 1.75 & 1.18 & 0.02 \\
\hline $\begin{array}{l}\text { Sporobolus pyramidalis } \\
\text { P. Beauv. }\end{array}$ & Poaceae & Faux gazon & Togo15537 & Rt, Fe & Pow/Top & $\begin{array}{l}\text { Breast, } \\
\text { chronic } \\
\text { wound }\end{array}$ & 3.51 & 2.35 & 0.03 \\
\hline Tamarindus indica L. & Caesalpiniaceae & Nidié/K & Togo15562 & Fr & Pow/Top & Breast & 1.75 & 1.18 & 0.02 \\
\hline $\begin{array}{l}\text { Tapinanthus oleifolius (J. } \\
\text { C. Wendl.) Danser }\end{array}$ & Loranthaceae & Gui rouge & Togo15563 & St & Pow/Top & Breast & 1.75 & 1.18 & 0.02 \\
\hline Theobroma cacao L. & Sterculiaceae & Cocoo/K & Togo15564 & Le & Dec/Top & $\begin{array}{l}\text { Chronic } \\
\text { wound }\end{array}$ & 1.75 & 1.18 & 0.02 \\
\hline $\begin{array}{l}\text { Vitellaria paradoxa C. F. } \\
\text { Gaertn. }\end{array}$ & Sapotaceae & Woussa/T & Togo15522 & $\begin{array}{c}\text { Stb, } \\
\text { Rt }\end{array}$ & Dec, Sauc/Orl & $\begin{array}{l}\text { Breast, } \\
\text { chronic } \\
\text { wound, } \\
\text { brain }\end{array}$ & 10.53 & 7.06 & 0.10 \\
\hline Waltheria indica L. & Sterculiaceae & $\begin{array}{c}\text { Fafouloumou/ } \\
\mathrm{T}\end{array}$ & Togo15499 & Rt & Dec/Orl & Lung & 1.75 & 1.18 & 0.02 \\
\hline $\begin{array}{l}\text { Xylopia aethiopica } \\
\text { (Dunal) A. Rich. }\end{array}$ & Annonaceae & Soussi/K & Togo15492 & Fr & $\begin{array}{l}\text { Dec, Sauc/Orl; } \\
\text { Bba }\end{array}$ & $\begin{array}{l}\text { Bone, } \\
\text { chronic } \\
\text { wound, } \\
\text { liver, breast }\end{array}$ & 21.05 & 15.29 & 0.19 \\
\hline $\begin{array}{l}\text { Zanthoxylum } \\
\text { zanthoxyloides L. }\end{array}$ & Rubiaceae & Kalao/K & Togo15561 & Rtb & $\begin{array}{c}\text { Pow, sau, orl/ } \\
\text { Top }\end{array}$ & Breast & 1.75 & 1.18 & 0.02 \\
\hline Zea mays L. & Poaceae & Samiriè/K & Togo15538 & St & Pow/Orl & $\begin{array}{l}\text { Lung, } \\
\text { chronic } \\
\text { wound }\end{array}$ & 3.51 & 2.35 & 0.03 \\
\hline $\begin{array}{l}\text { Zingiber officinale } \\
\text { Roscoe }\end{array}$ & Zingiberaceae & Wissikoè/K & Togo15539 & $\mathrm{Rz}$ & Pow/Orl & Breast & 3.51 & 2.35 & 0.03 \\
\hline
\end{tabular}

Local names: $\mathrm{E}=$ Ewé; $\mathrm{K}=$ Kabyè; $\mathrm{T}=\mathrm{Tem}$. Used parts: $\mathrm{Stb}=$ stem barks, $\mathrm{Le}=$ leaves, $\mathrm{Rtb}=$ root barks, $\mathrm{Fr}=$ fruit, $\mathrm{Rt}=$ roots, $\mathrm{Rz}=$ rhizomes, $\mathrm{Bu}=$ bulbs, and $\mathrm{Se}=$ seeds. Mode of preparation and administration routes: $\mathrm{Dec} / \mathrm{Orl}=$ decoction and oral route, $\mathrm{Mac} / \mathrm{Orl}=$ maceration and oral route, Dec, Mac/ $\mathrm{Orl}=$ decoction or maceration and oral route, $\mathrm{Mac} / \mathrm{Bba}=$ maceration and body bath, Sau/Orl = sauce and oral route, Pow/Orl = Powder and oral route, Dec, Sauc/Orl $=$ Decoction or sauce and oral route, Pow/Top $=$ Powder and Topical route, and Pow $/$ Nas $=$ Powder and nasal route.

said to be obliged to manage a garden for some plant species. Similar observations have been reported in the study by Agyare et al. [16] in Ghana. In our study, about $88.71 \%$ said that the plants are available in forests while $11.29 \%$ reported that they sometimes have problems with the collection due to seasonal unavailability. For 96.92\%, identification of the herbal material is made by themselves in most cases as they state that they have long experience in their field.

3.4. Plant Parts Used and Recipes' Preparation. The traditional healers of our study area use different parts of the plants for their concoctions. Leaves and roots are the most 
TABLE 2: Plants used for the treatment of tumors and chronic wounds from groups I, II, and III.

\begin{tabular}{lcccc}
\hline Group I: more than 10 citations & Frequency & Group II: from 10 to 7 citations & Frequency & Group III: from 6 to 4 citations Frequency \\
\hline & & Aframomum melegueta & 8 & Blighia sapida \\
Xylopia aethiopica & \multirow{2}{*}{13} & Khaya senegalensis & 7 & Vitellaria paradoxa \\
& & Parkia biglobosa & 7 & Adansonia digitata \\
& & Piliostigma thonningii & 7 & Annona muricata \\
& & & Parinari curatellifolia
\end{tabular}

TABLE 3: Species cited for the two most tumors and chronic wound healing.

\begin{tabular}{|c|c|c|c|}
\hline Type of disease & Plant (botanical name) & Local name & Part used \\
\hline Breast tumor & 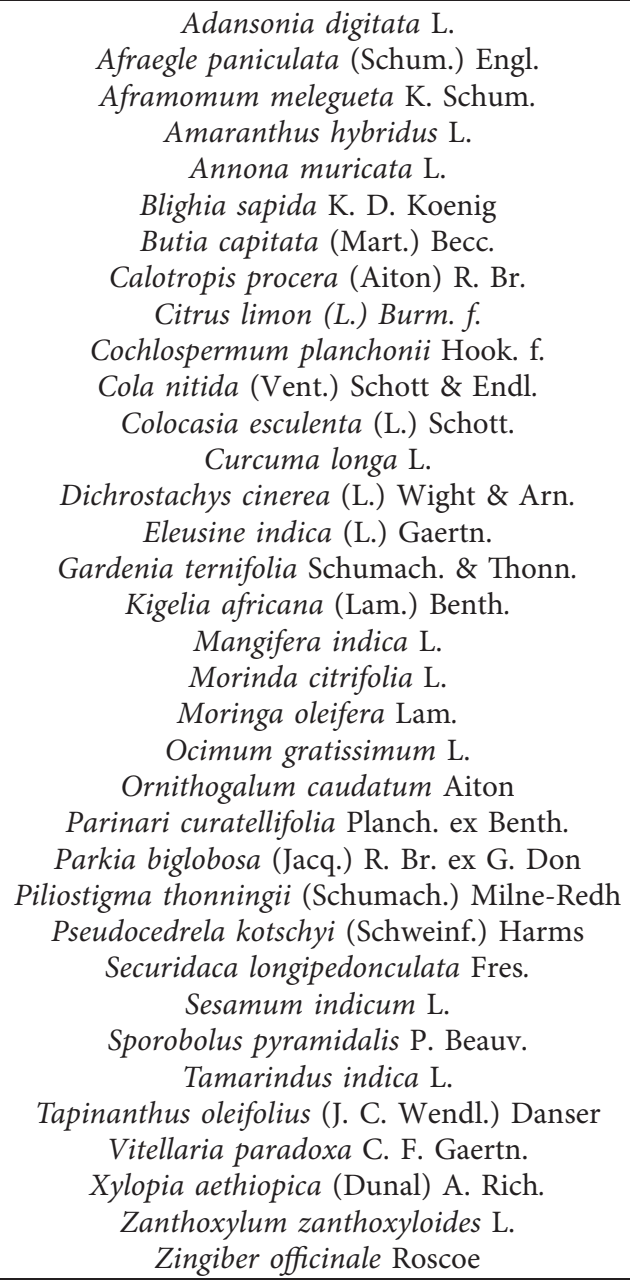 & $\begin{array}{c}\text { Télou/K } \\
\text { Ngoné/K } \\
\text { Colombo/K } \\
\text { Karatoutou } \\
\text { Agnigli/E } \\
\text { Kpizou } \\
\text { Foda kokolo/K } \\
\text { Kpakpadjoé/K } \\
\text { Gnami/K } \\
\text { Tèkalichoua/K } \\
\text { Coroo/T } \\
\text { Pankani/K } \\
\text { Curcuma } \\
\text { Sozossi/T } \\
\text { Adandala/T } \\
\text { Kao/K } \\
\text { Abiliou/T; Lémiré/K } \\
\text { Mango/K } \\
\text { Noni } \\
\text { Kpadadrè/K } \\
\text { Azèou/K; Estro/E } \\
\text { Aléwa gabou/K } \\
\text { Milioumiliou/T } \\
\text { Soulou/K } \\
\text { Eclo/E, Babakou/K } \\
\text { Doutotoré/T } \\
\text { Fozi/T } \\
\text { Goussi/E } \\
\text { Faux gazon } \\
\text { Nidié/K } \\
\text { Gui rouge } \\
\text { Woussa/T } \\
\text { Soussi/K } \\
\text { Kalao/K } \\
\text { Wissikoè/K } \\
\end{array}$ & $\begin{array}{l}\text { Stb, Fr } \\
\text { Sed } \\
\text { Fr } \\
\text { Rt, Le } \\
\text { Le } \\
\text { Le, Fr } \\
\text { Rt/Fr } \\
\text { Rt, le } \\
\text { Fr } \\
\text { Rt } \\
\text { Hul } \\
\text { Le } \\
\text { Rt } \\
\text { Rt } \\
\text { Rt } \\
\text { Rt } \\
\text { Le/Stb } \\
\text { Le, Stb } \\
\text { Fe } \\
\text { Le/Se } \\
\text { Le } \\
\text { Bu } \\
\text { Le, Rt, Rtb } \\
\text { Rt, Stb } \\
\text { Le, Rt } \\
\text { Rt, Le } \\
\text { Rt } \\
\text { Fr } \\
\text { Rt, Fe } \\
\text { Fr } \\
\text { St } \\
\text { Stb, Rt } \\
\text { Fr } \\
\text { Rtb } \\
\text { Rz } \\
\end{array}$ \\
\hline Lung tumor & $\begin{array}{c}\text { Abrus precatorius L. } \\
\text { Allium sativum L. } \\
\text { Annona muricata L. } \\
\text { Blighia sapida K. D. Koenig } \\
\text { Carica papaya L. } \\
\text { Combretum collinum Fresen. } \\
\text { Daniellia oliveri (Rolfe) Hutch. \& Dalziel } \\
\text { Ocimum gratissimum L. } \\
\text { Opilia amentacea Roxb. } \\
\text { Panax gingeng } \\
\text { Parinari curatellifolia Planch. ex Benth. } \\
\text { Piliostigma thonningii (Schumach.) Milne-Redh } \\
\text { Sarcocephalus latifolius (Sm.) E. A. Bruce } \\
\text { Senna siamea (Lam.) H. S. Irwin \& Barneby } \\
\text { Waltheria indica L. } \\
\text { Zea mays L. }\end{array}$ & $\begin{array}{l}\text { Adodobia fadi/T } \\
\text { Aiyo/E } \\
\text { Agnigli/E } \\
\text { Kpizou } \\
\text { Somboré/K } \\
\text { Fokizao/T } \\
\text { Tchèlè/T } \\
\text { Azèou/K; Estro/E } \\
\text { Kalibinou/K } \\
\text { Ginseng } \\
\text { Milioumiliou/T } \\
\text { Eclo/E, Babakou/K } \\
\text { Kitchatchalou } \\
\text { Zanguerati/E } \\
\text { Fafouloumou/T } \\
\text { Samiriè/K }\end{array}$ & $\begin{array}{l}\text { Le } \\
\text { Fr } \\
\text { Le } \\
\text { Le, Fr } \\
\text { Rt } \\
\text { Rt } \\
\text { Le } \\
\text { Le } \\
\text { Rt } \\
\text { Rt } \\
\text { Le, Rt, Rtb } \\
\text { Le, Rt } \\
\text { Rt, Stb } \\
\text { Le } \\
\text { Rt } \\
\text { St }\end{array}$ \\
\hline
\end{tabular}


TABLE 3: Continued.

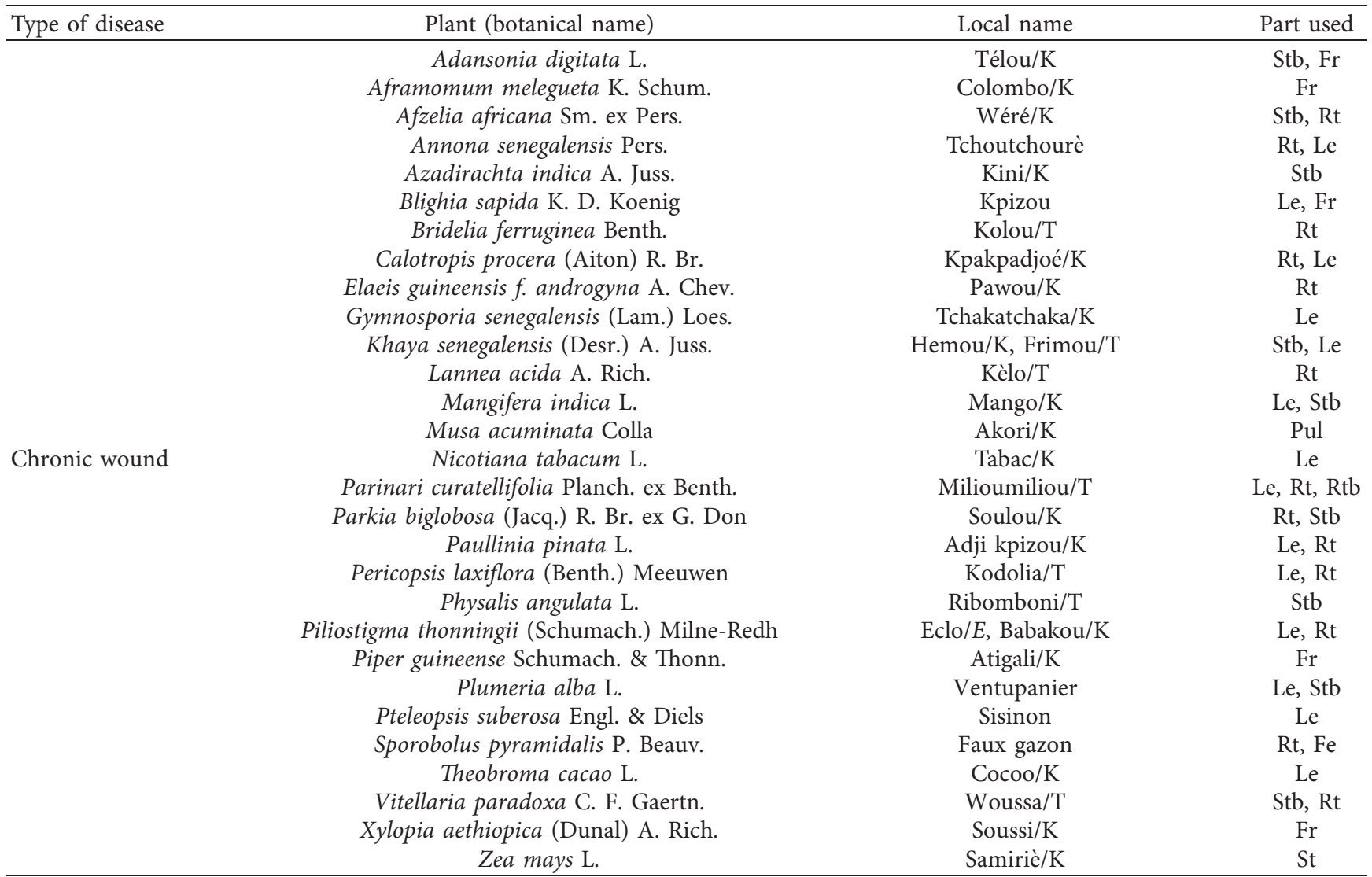

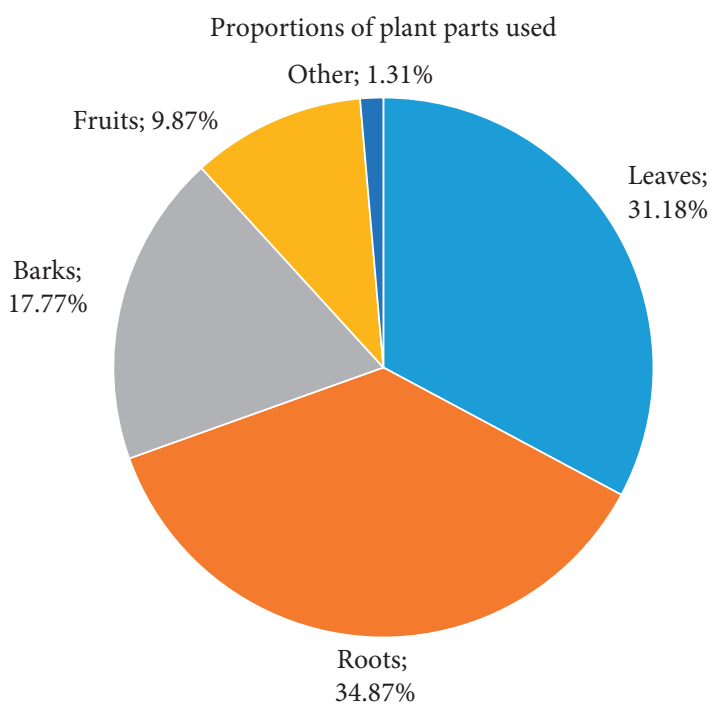

Figure 3: Plant parts used.

used parts (Figure 3). This finding is in line with the ethnopharmacological studies conducted by Koudouvo et al. [17] in the Maritime region of Togo on antimalarial plants and Kantati et al. [18] on central nervous system disorders in Togo. Frequent use of roots is a threat to plant biodiversity. Eighty-five herbal remedies which included decoctions (40\%), powder (37.65\%), sauce (15.29\%), dough $(4.71 \%)$, and maceration $(2.35 \%)$ were listed by the traditional healers for treating cancer and tumors. About $87.30 \%$ of the recipes proposed are in association with two or more plants. It reflects the results of Segun et al. [13]. This association is a common practice in traditional medicine where practitioners find it beneficial because polyherbal therapy has the advantage of producing maximum therapeutic effects with minimum side effects [31].

Administration routes of recipes are mainly the oral route and the topic application. Most recipes are administered twice or once a day. According to $68 \%$ of traditional healers, the duration of tumor management with medicinal plants is very variable, ranging from one to three months, depending on the case. For the majority of traditional healers (71.64\%), their preparations are kept in cans or bottles. The management of cancer in our study, mainly from one to three months and often unknown, reflects the complexity of the disease and its multifactorial aspects.

3.5. Traditional Healers' Needs. During our investigation, we wanted to know which needs traditional healers were expecting from university researchers and the Togolese government. Ninety percent of traditional healers request training sessions on the basics of cancer such as symptoms, good methods of plant transformation, and the processing of their medicines. They are also seeking support from the government for recognition of their activities and the 
opening of pharmacies for traditional medicines. They said that they make a huge contribution to people's health. Many patients go to them for the lack of financial means and conventional health structures as well as for the effectiveness of their treatments.

\section{Conclusion}

This ethnopharmacological survey on tumors and cancers in two regions of Togo revealed that traditional healers had an endogenous understanding of tumors and cancers. The present study documented seventy anticancer medicinal plant species. As the emergence of resistance to cancer chemotherapy is a deep concern, Togolese flora must be explored for new bioactive anticancer drugs. The commonly recommended strategy in the discovery of drugs is to evaluate plant extracts in vitro and in vivo to confirm their therapeutic potential. Keeping this in mind, our ethnopharmacological survey is the first step before confirmation in vitro and in vivo. Work is in progress to validate the antioxidant, anti-inflammatory, and antitumor effects of some species in different models.

\section{Data Availability}

The data used to support the findings of this study are included within the article.

\section{Conflicts of Interest}

The authors declare that there are no conflicts of interest regarding the publication of this paper.

\section{Acknowledgments}

We are grateful to the members of CERMETRA of the two regions who participated in this survey. Our special thanks are due to the coordinator for his principal management. We are also grateful to the staff members of the herbarium of the University of Lomé.

\section{References}

[1] F. Bray, J. Ferlay, I. Soerjomataram, R. L. Siegel, L. A. Torre, and A. Jemal, "Global cancer statistics 2018: GLOBOCAN estimates of incidence and mortality worldwide for 36 cancers in 185 countries," CA: A Cancer Journal for Clinicians, vol. 68, no. 6, pp. 394-424, 2018.

[2] F. Balkwill and A. Mantovani, "Inflammation and cancer: back to Virchow?" The Lancet, vol. 357, no. 9255, pp. 539-545, 2001.

[3] B. B. Aggarwal, S. Shishodia, S. K. Sandur, M. K. Pandey, and G. Sethi, "Inflammation and cancer: how hot is the link?" Biochemical Pharmacology, vol. 72, no. 11, pp. 1605-1621, 2006.

[4] V. Hannelien, G. Karel, V. D. Jo, and S. Sofie, "The role of CXC chemokines in the transition of chronic inflammation to esophageal and gastric cancer," Biochimica et Biophysica Acta (BBA)-Reviews on Cancer, vol. 1825, no. 1, pp. 117-129, 2013.

[5] H. Ohshima, H. Tazawa, B. S. Sylla, and T. Sawa, "Prevention of human cancer by modulation of chronic inflammatory processes," Mutation Research/Fundamental and Molecular Mechanisms of Mutagenesis, vol. 591, no. 1-2, pp. 110-122, 2005.

[6] M. Saravanan, P. Senthilkumar, V. Chinnadurai, K. Murugesan Sakthivel, R. Rajeshkumar, and A. Pugazhendhi, "Antiangiogenic, anti-inflammatory and their antioxidant activities of Turnera subulata Sm. (Turneraceae)," Process Biochemistry, vol. 89, pp. 71-80, 2020.

[7] O. Awoyemi, I. Abdulkarim, E. Ewa, and A. Aduloju, "Ethnobotanical assessment of herbal plants in South-Western Nigeria," Academic Research International, vol. 2, no. 3, pp. 50-57, 2012.

[8] A. Nyika, "Ethical and regulatory issues surrounding African traditional medicine in the context of HIV/AIDS," Developing World Bioethics, vol. 7, no. 1, pp. 25-34, 2007.

[9] A. Takke and P. Shende, "Nanotherapeutic silibinin: an insight of phytomedicine in healthcare reformation," Nanomedicine: Nanotechnology, Biology and Medicine, vol. 21, Article ID 102057, 2019.

[10] S. M. El-Hallouty, W. Fayad, N. H. Meky, B. S. EL-Menshawi, G. M. Wassel, and A. A. Hasabo, "In vitro anticancer activity of some Egyptian plant extracts against different human cancer cell lines," International Journal of Pharmtech Research, vol. 8, no. 2, pp. 267-272, 2015.

[11] E. Solowey, M. Lichtenstein, S. Sallon, H. Paavilainen, E. Solowey, and H. Lorberboum-Galski, "Evaluating medicinal plants for anticancer activity," The Scientific World Journal, vol. 2014, Article ID 721402, 12 pages, 2014.

[12] A. J. Alonso-Castro, M. L. Villarreal, L. A. Salazar-Olivo, M. Gomez-Sanchez, F. Dominguez, and A. Garcia-Carranca, "Mexican medicinal plants used for cancer treatment: pharmacological, phytochemical and ethnobotanical studies," Journal of Ethnopharmacology, vol. 133, no. 3, pp. 945-972, 2011.

[13] P. A. Segun, O. O. Ogbole, and E. O. Ajaiyeoba, "Medicinal plants used in the management of cancer among the Ijebus of Southwestern Nigeria," Journal of Herbal Medicine, vol. 14, pp. 68-75, 2018.

[14] V. Kuete and T. Efferth, "African flora has the potential to fight multidrug resistance of cancer," Biomed Research International, vol. 2015, Article ID 914813, 24 pages, 2015.

[15] J. M. Alves-Silva, A. Romane, T. Efferth, and L. Salgueiro, "North African medicinal plants traditionally used in cancer therapy," Frontiers in Pharmacology, vol. 8, p. 383, 2017.

[16] C. Agyare, V. Spiegler, A. Asase, M. Scholz, G. Hempel, and A. Hensel, "An ethnopharmacological survey of medicinal plants traditionally used for cancer treatment in the Ashanti region, Ghana," Journal of Ethnopharmacology, vol. 212, pp. 137-152, 2018.

[17] K. Koudouvo, D. S. Karou, K. Kokou et al., "An ethnobotanical study of antimalarial plants in Togo Maritime Region," Journal of Ethnopharmacology, vol. 134, no. 1, pp. 183-190, 2011.

[18] Y. T. Kantati, K. M. Kodjo, K. S. Dogbeavou, D. Vaudry, J. Leprince, and M. Gbeassor, "Ethnopharmacological survey of plant species used in folk medicine against central nervous system disorders in Togo," Journal of Ethnopharmacology, vol. 181, pp. 214-220, 2016.

[19] T. Alfa, K. Anani, Y. Adjrah, K. Batawila, and Y. Ameyapoh, "Ethnobotanical survey of medicinal plants used against fungal infections in prefecture of sotouboua central region, Togo," European Scientific Journal, ESJ, vol. 14, no. 3, p. 342, 2018.

[20] T. Tchacondo, S. D. Karou, A. Agban et al., "Medicinal plants use in central Togo (Africa) with an emphasis on the timing," Pharmacognosy Research, vol. 4, no. 2, p. 92, 2012.

[21] S. D. Karou, T. Tchacondo, M. A. Djikpo Tchibozo et al., "Ethnobotanical study of medicinal plants used in the 
management of diabetes mellitus and hypertension in the Central Region of Togo," Pharmaceutical Biology, vol. 49, no. 12, pp. 1286-1297, 2011.

[22] W. R. Sawadogo, M. Schumacher, M.-H. Teiten, M. Dicato, and M. Diederich, "Traditional West African pharmacopeia, plants and derived compounds for cancer therapy," Biochemical Pharmacology, vol. 84, no. 10, pp. 1225-1240, 2012.

[23] A. Katiri, M. Barkaoui, F. Msanda, and H. Boubaker, "Ethnobotanical survey of medicinal plants used for the treatment of diabetes in the Tizi n'Test region (Taroudant Province, Morocco)," Journal of Pharmacognosy Natural Products, vol. 3, no. 1, pp. 2472-0992, 2017.

[24] L. Gazzaneo, R. De Lucena, and U. de Albuquerque, "Knowledge and use of medicinal plants by local specialists in an region of Atlantic Forest in the state of Pernambuco (Northeastern Brazil)," Journal of Ethnobiology and Ethnomedicine, vol. 1, no. 1, p. 9, 2005.

[25] M.-L. Avana-Tientcheu, C. H. Sime, R. Tsobou, and Z. Tchoundjeu, "Diversity, ethnobotanical potential and sustainability assessment of plants used by traditional healers to treat cancer in Boyo division, North-West region, Cameroon," European Journal of Medicinal Plants, vol. 27, pp. 1-22, 2019.

[26] C. Agyare, A. Asase, M. Lechtenberg, M. Niehues, A. Deters, and A. Hensel, "An ethnopharmacological survey and in vitro confirmation of ethnopharmacological use of medicinal plants used for wound healing in Bosomtwi-AtwimaKwanwoma area, Ghana," Journal of Ethnopharmacology, vol. 125, no. 3, pp. 393-403, 2009.

[27] C. Agyare, V. Spiegler, H. Sarkodie, A. Asase, E. Liebau, and A. Hensel, "An ethnopharmacological survey and in vitro confirmation of the ethnopharmacological use of medicinal plants as anthelmintic remedies in the Ashanti region, in the central part of Ghana," Journal of Ethnopharmacology, vol. 158, pp. 255-263, 2014.

[28] J. S. Ashidi, P. J. Houghton, P. J. Hylands, and T. Efferth, "Ethnobotanical survey and cytotoxicity testing of plants of South-western Nigeria used to treat cancer, with isolation of cytotoxic constituents from Cajanus cajan Millsp. leaves," Journal of Ethnopharmacology, vol. 128, no. 2, pp. 501-512, 2010.

[29] V. Kuete, B. Krusche, M. Youns et al., "Cytotoxicity of some Cameroonian spices and selected medicinal plant extracts," Journal of Ethnopharmacology, vol. 134, no. 3, pp. 803-812, 2011.

[30] N. F. Bussa and A. Belayneh, "Traditional medicinal plants used to treat cancer, tumors and inflammatory ailments in Harari Region, Eastern Ethiopia," South African Journal of Botany, vol. 122, pp. 360-368, 2019.

[31] P. E. Ebong, I. J. Atangwho, E. U. Eyong, and G. E. Egbung, "The antidiabetic efficacy of combined extracts from two continental plants: Azadirachta indica (A. Juss) (neem) and vernonia amygdalina (del.) (african bitter leaf)," American Journal of Biochemistry and Biotechnology, vol. 4, no. 3, pp. 239-244, 2008. 